\title{
Student accounts of space and safety at a South African university: implications for social identities and diversity
}

\author{
Tamara Shefer, Anna Strebel, Sisa Ngabaza and Lindsay Clowes
}

\begin{abstract}
Transformation efforts in South African higher education have been under increased scrutiny in recent years, especially following the last years of student activism and calls for decolonization of universities. This article presents data from a participatory photovoice study in which a group of students reflect on their experiences of feeling safe and unsafe at an urban-based historically disadvantaged university. Findings highlight the way in which historical inequalities on the basis of social identities of race, class, and gender, among others, continue to shape experiences, both materially and social-psychologically, in South African higher education. However, and of particular relevance in thinking about a socially just university, participants speak about the value of diversity in facilitating their sense of both material and subjective safety. Thus, a diverse classroom and one that acknowledges and recognizes students across diversities, is experienced as a space of comfort, belonging and safety. Drawing on feminist work on social justice, we argue the importance of lecturer sensitivity and reflexivity to their own practices, as well as the value of social justice pedagogies that not only focus on issues of diversity and equality but also destabilize dominant forms of didactic pedagogy, and engage students' diverse experiences and perceptions.
\end{abstract}

Post-apartheid South Africa remains a country fraught by inequalities, in which historical divides continue. Higher education, currently under increased scrutiny given recent student activism, is clearly not exempt from these divisions. The transformation of universities has been viewed as a priority since 1994 (Department of Education, 1997, 2008; Department of Higher Education and Training, 2010), with the events of the past year ushering in a new urgency and shifting terrain in higher education (Badat, 2016; Mbembe, 2015). Thus, while the Report of the Ministerial Committee on Transformation and Social Cohesion and the Elimination of Discrimination in Public Higher Education Institutions (Department of Education, 2008), also colloquially known as the Transformation Report, documented continuing challenges with respect to exclusionary and discriminatory practices on the basis of gender, race, class and other social inequalities, student protests further articulated a groundswell of dissatisfaction with the lack of progress in transforming higher education, and with social change more broadly in South Africa (Badat, 2016). 
The focus on research and practice with respect to teaching and learning, and consideration of experiences of historical and continued inequalities, have accelerated over the last few years, with a growing emphasis on teaching and learning that is transformatory and challenges didactic normative methods (Bozalek \& Boughey, 2012; Bozalek \& Carolissen, 2012; Clowes, 2013b). There is also a substantial amount of research exploring different kinds of pedagogical approaches to questions of inequality and diversity, and instances where teachers reflect critically on their own and each other's practice, as well as the extent to which they themselves are implicated in re-inscribing the inequalities they hope to challenge (Clowes, 2013b; Jansen, 2009; Matias \& Grosland, 2016; Robus \& Macleod, 2006; Soudien, 2012). At the same time, studies are foregrounding student narratives (Clowes, 2013a; Gachago, Ivala, Condy, \& Chigona, 2013; Ngabaza, Bojarczuk, Masuku, \& Roelfse, 2015; Ngabaza, Daniels, Frank, \& Maluleke, 2013).

In documenting and exploring narratives of students with respect to issues of diversity, social and group identity, and social divisions as they shape contemporary experiences of teaching and learning in higher education, such studies are increasingly important. One example is the digital storytelling project at a university of technology in the Western Cape (Condy, 2015), and the possibilities and constraints such narratives present for challenging or re-inscribing dominant discourses (Gachago, Cronje, Ivala, Condy, \& Chigona, 2014). In another project, Bozalek and colleagues (Bozalek et al., 2010; Leibowitz et al., 2012; Rohleder, Swartz, Carolissen, Bozalek, \& Leibowitz, 2008) devised a large, cross-institutional social justice pedagogical project, hinging around a shared module for students in two different and unequal universities, in an effort to challenge apartheid legacies of geographical separation which continue to impact on contemporary South African higher education. These researchers document the value of working across diversity for critical and social justice projects in higher education, and for developing reflexive and responsible citizenship that is committed to larger social good. Such studies foreground the way in which contexts of higher education reflect and serve to re-inforce and reproduce entrenched social and group identities in multiple and complex ways, but, as noted above, may also be deployed in creative ways to challenge reified identities, and othering and marginalizing practices.

Based on an analysis of findings from a study conducted by and with university students on their experiences at a South African university, this article hopes to contribute to the growing body of literature that explores how diverse social identities shape experience in higher education. It seems especially important, in the light of current student protests and calls for decolonization, that we understand the lived experiences of students on campus, and how the remains of apartheid and colonization continue to shape experiences and impact on the pedagogical project. In this respect, the article also aims to contribute to thinking about critical and social justice pedagogical practices within a context that acknowledges that both universities and the larger South African context remain fraught by material and discursive inequalities, and destructive, divisive and discriminatory practices. In reflecting on a group of students' stories about feelings of being safe and unsafe at the university, the findings flag the salience of continued

\section{http://repository.uwc.ac.za}


discourses of race, class and gender in such reported experiences of students on campus. Yet the study also documents the growing spaces for contestation of rigid practices of naming identity, and the value of foregrounding multiple and fluid diversity and difference in socially just pedagogical practice.

\section{Method}

\section{Participants}

This study draws on the experiences of 147 third-year students (31\% male and 69\% female) in a research methodology class in an Arts Faculty Department at a historically disadvantaged university located in an urban setting that was in the apartheid system of segregation designated for Coloured students. Reflecting regional demographics, the majority of students in the class are those historically classified as Coloured (58\%) and African (36\%) with a minority of White students (6\%). ${ }^{1}$ While we have no statistical measure of the class background of this group of students, this university continues to cater to a majority of highly disadvantaged students, many of whom rely on state grants to study, are first generation university students, and come from poverty stricken communities and families.

\section{Procedure}

This was a photovoice research project implemented as part of a third year research module. Photovoice is a participatory action research method where participants take photographs to express their subjective voices on a particular research phenomenon (Wang \& Burris, 1997). It has been recognized for its value particularly in engaging young people in a participatory and non-exploitative way in social justice projects, as well as in gathering data that are meaningful for social justice (see Kessi, 2011; Suffla, Kaminer, \& Bawa, 2012).

As part of an authentic learning and enquiry-based project in learning research methodologies (Shefer \& Clowes, 2015; see also Ngabaza et al., 2015; Ngabaza et al., 2013), final year students engage in a research project in which they learn research methodology and gain practice-based experience through conducting a small research project. Each year, the class focuses on a different social justice topic. In 2014, students were required to take two photos about spaces that were safe and two that were unsafe in their experiences of the campus and write short narratives about these. Students were asked to use their own cell phones to take the photos. Students' data, both photos and accompanying narratives, were uploaded electronically for the analysis. While students drew on their own photonarrative data to submit an examinable report, the researchers in the reported study drew on the full set of narratives for their analysis.

\section{Ethical considerations}

Ethical approval for the research was obtained from the university concerned. All standard ethical considerations for research with human participants were adhered to, and particular care was taken to address power inequalities inherent in research involving students and teachers. Students signed a consent form on the basis of informed consent guaranteeing confidentiality and anonymity. While all students needed to conduct the study and submit

\section{http://repository.uwc.ac.za}


their data for assessment, the consent form allowed their data to be excluded from the study if they so wished. Notably, no students in the year under study or in the past have requested exclusion from the study.

\section{Data analysis}

A content analysis of the photonarratives was initially conducted to identify the range and frequency of places perceived as safe and unsafe by participants, as reported elsewhere (Ngabaza et al., 2015). Further qualitative thematic analysis produced an overall picture of the factors contributing to these student perceptions. While the photos themselves were a rich source of data, in this article we focus primarily on the narratives generated in relation to the photos rather than attempt to analyse the photos themselves, which is a further project. In reflecting on experiences of feeling safe and unsafe on campus, students foregrounded identities structured around race, gender, class, sexuality and other subject locations emerging out of South African history. The analysis that follows, that explores experiences of inclusion and or exclusion in student narratives, thus employs an intersectional lens acknowledging that these identities - expressions of inequality - are co-constituted and mediate each other. Attributed to Crenshaw (1991), the notion of intersectionality, while not uncontested (see McCall, 2005), provides a lens for acknowledging the nuances of social identity and practices of power, in particular the entanglement of different forms of discursive and material identity in shaping experience. Intersectionality is helpful in destabilizing the 'additive logic in which the axes of subordination simply compound one other' (BernardinoCosta, 2014, p. 73) to allow for an appreciation of the complex interaction of multiple forms of social identity, differentiation and power in shaping experience. It is within this framework that we approach and unpack students' narratives of their experiences of feeling safe and unsafe on a university campus.

\section{Results and discussion}

Two dominant themes emerged from the analysis. One highlighted the continued sense of othering that students experienced, that was clearly linked to experiences of feeling unsafe, as well as exclusion and discomfort articulated around particular social identities located within historical and current inequalities of (post)apartheid South Africa. The other speaks to ways in which diversity and the appreciation and acknowledgment of difference, in pedagogical and other practices, may lead to a sense of safety, belonging and inclusion, serving to challenge previously entrenched negative experiences of diversity.

\section{Intersectional identities and continued divides and 'othering'}

The dominant differences in social identity, which according to students contributed to experiences of feeling unsafe on the university campus, centered around historical and current power inequalities in local and global contexts, including those of gender, sexuality, race, class and citizenship, and the ways in which these were understood to expose or protect them from harm (see also Whitehead, 2012).

\section{http://repository.uwc.ac.za}




\section{Gendered identities and feeling unsafe.}

Many women students, as well as some men, identified gender as a salient contributor to experiences of safety or not on the university campus, with women feeling or being seen as less safe than men, especially when they were alone:

As a woman I am afraid to use the staircase as I feel anything could happen and there would be no-one around to help me if someone attacks me. (Black ${ }^{2}$ female)

Although this area is frequented mostly by men at night, it is the female students who are unsafe and fear to walk there after dark. (Coloured female)

There was also a strong sentiment that women were not as physically strong as men, so more vulnerable to experiences of attack, rape, muggings, and violence in general. While this relies on a stereotypic notion of superior male physical strength, the discursive framing of women as inevitable victims and inherently vulnerable to violence has also been shown to operate in contexts of higher education (as elsewhere) in both the regulation of women and punitive responses to their violation, since 'they should have known better' (Bennett, 2005; Dosekun, 2007; Gordon \& Collins, 2013). Some examples of the construction of women as vulnerable to male violence and the regulatory effects, that is, the setting up of mechanisms and cautionary strategies, on women were evident in students' narratives:

I also avoid [the campus pub] at night because I am female and men get drunk and take advantage of women because they are stronger. (CF)

I travel with my cousin who is also a female, yet I still feel unsafe . . perhaps if we were accompanied by a male student we would feel safer as he would be able to protect us. (CF)

Moreover, there was a consciousness among some women of how their female bodies placed them at particular risk, foregounding both a reflexive critique of how such fears of male violence shape experiences and practices, as well as a resignation to this, a sense of inevitability:

I feel sexually unsafe exposing myself in this manner, especially following several instances of men in the taxi whistling and commenting ... I feel certain that I would not experience this if I was a male ... Again, I would think that this is more common for girls, due to the intensity of the body pressure we face. (White female)

Raced identity. Racial identity, founded apparently on a continued subscription to apartheid categorizations of identity, was regarded as key to perceptions of personal safeness, in a number of ways that seemed to reflect notions of 'othering' and exclusion. Reflecting other local studies, including the Ministerial Report on Transformation (Department of Education, 2008) cited earlier, that flag the continued salience of race and raced and classed difference and inequality on South African campuses (Bhana, 2014; Pattman, 2007; Vincent, 2008), the significance of race and an assumption of essentialized

\section{http://repository.uwc.ac.za}


racialized groups emerged as a key discourse in narratives on safe and unsafe spaces. Students report how some spaces on campus were seen to be frequented mainly by one or other group, resulting in members of the dominant group feeling safe because of this:

As a female student who was classified under the apartheid era as 'coloured' I particularly highlight this space as safe based on my race, because this is a space where most 'coloured' students hang out. (CF)

I feel safe in this place because there are many black guys and women works there, so it makes it easier for me to communicate with them with anything. (BM)

Conversely those of the minority group reported feeling unsafe in spaces that were dominated by a particular group constructed on the basis of prescribed race or ethnicity, which frequently deployed racist stereotypes:

For some reason I was more afraid of what the coloured person would do because I always have the impression that coloured people are unpredictable and aggressive. I am from a black community. (AM)

On the other hand, shared racial identity was clearly not always a contributor to feeling safe, especially when intersecting with other forms of difference and power, in this case gender. Again the narrative below flags certain stereotypes associated with a particular group, reflecting intersectional negative representations that dominate the public imaginary:

When I see males especially Coloured males dressed slobby or gangster like walking toward me I immediately experience anxiety and start to clamp onto my belongings. As a Coloured person myself, I feel especially unsafe and vulnerable because I have this idea that they might reason it is acceptable to rob someone of their own racial group. (CF)

Moreover, raced discourses powerfully intersected with gender, so that, for example, Black men were seen as especially threatening to Coloured women on their own, further highlighting the way in which apartheid categories, and stigmatization of Black men in particular, continue to shape constructions of subjectivity and group divides:

One day I was walking alone . . . and a 'black' male student came running-walking behind me. Based on other peoples' experiences and narratives of 'black' males attacking females, I instantly assume that he is going to violate me and fear and anxiety full up my whole body. (CF)

Coloured and white groups of students, mostly female, would feel differently in this space because black people are mostly feared at night. (BM) 
Evident in these quotes is an othering of Black men, particularly poor, young Black men, stereotyped as inherently threatening and violent. This discourse has been deconstructed as salient in (post)apartheid ideology (Dosekun, 2007; Ratele, 2014; Shefer, 2016).

At the same time, while still enjoying privilege in larger society, those who do not historically 'belong' at a 'Coloured' university, such as White women, felt that they were objects of uncomfortable scrutiny:

Because of my race I often feel discriminated and stereotyped - this may be influenced by the fact that I am attending what was known within the apartheid era as a 'coloured' university. (WF)

Interestingly there were also Black men who saw their racial identity as a contributor to feelings of safeness on campus. Thus, some students coming from townships shared how they find the levels of security on the campus re-assuring, or that they were 'used' to 'dangerous places' and so did not generally feel unsafe here:

As the man coming from informal settlement or shacks (in township), I don't live in fear ... as a Xhosa man I was raised to be strong and be brave; also as a 21 year old male, I don't live in fear as there's no reason to. (BM)

The student feels safe in this space because he is a black male student who comes from the townships, and has never lived in a place which has cameras and securities and has group of mixed racial groups. (BM)

These narratives flag how particular kinds of masculinity (or rather masculinity in harsh environments) may be interpreted as protective for male narrators while constituting a threatening identity for others, as emerges in some of the female narratives. Notably, the narratives highlight how male students, constructed in racialized terms by participants as Coloured or Black, appear to feel most safe while representing those who are most feared.3 Such a finding relates both to a history of raced, classed and gendered dominant representation, as well as the way in which such intersectional experiences shape experiences of feeling safe and unsafe on campus, and the role of fear in regulating and policing women's mobility in particular, as unpacked earlier.

\section{Classed identities.}

Class identity also emerged as shaping experiences of feeling safe. On the one hand, working class students, who were unable to afford motor cars, felt themselves vulnerable in having to make use of public transport, especially the nearby train station and surrounds:

Most of the students that make use of this route [leading to railway station] are either travelling by foot or by train. The students that thus make use of this path, are usually associated as poorer than those who travel by car ... This also shows how this class is treated, as security is not as secure at this part of the campus. (CM)

\section{http://repository.uwc.ac.za}


It is mostly students from poorer communities who do not have their own cars who travel by train. The better off students would never travel by train because it is not a safe option. (CF)

On the other hand, places frequented by middle class students, for example, eating places charging more for food, were thought to be safer:

One generally finds that the individuals who go to [name of eatery] for a meal or for study purposes are of the middle to upper class. This makes me feel at ease as I feel that I am therefore not a target and rather that I am in a space of equality, regardless of my race or gender. (WF)

I also feel safe because the people that buy food at the deli may fall in the middle class category because the food is expensive. (CF)

However, poorer students also felt threatened by places frequented by wealthier students, since they felt stigmatized by their lack of access to markers of wealth such as having money to buy the expensive food and having a car:

This is a space where I do not find myself safe or comfortable because most of the times it is filled with people eating food that is not affordable to everyone. Also people who relax at this space mostly own cars

... as I'm from a family that is not wealthy at all, I find it uncomfortable to be at this space which people that are not of my class. (BM)

The significance of material capital on university campuses, such as access to a car, cell phones, and others luxuries, have been well illustrated in the local literature on transactional sexual practices in higher education (Gukurume, 2011; Masvawure, 2010; Shefer, Clowes, \& Vergnani, 2012).

\section{Emotional and physical spaces of diversity enhance feelings of safety}

Notably, and of relevance for social justice efforts in higher education, there was a strong narrative among participants regarding the sense of safeness which was experienced in spaces characterized by diverse identities. This seemed to involve a number of dimensions. First, there was a sentiment that being in venues which were frequented by a diversity of people provided a measure of safety and comfort:

I consider this to be safe area for me due to the fact that all seem to be welcome, those occupying it at any given time ... There are no specific or fixed social group, race or gender that occupies these areas on a constant level. This could be the reason for the feeling of security and safety. (CM) 
As a black gay man I always look at how different genders, sexualities and ethnicities are represented in a space and I find the more diverse, the more accepting, the more safe. (BM)

Venues that were experienced positively, precisely because of the diversity of students frequenting them, included the student centre and main library, contrasting with common belief that non-diverse spaces offer safety for marginalized groups, such as lesbian, gay, bisexual, transgender, intersex and queer (LGTIQ+). It may be that in such places, any markers of difference are over-shadowed by a common purpose and shared right and invitation, as member of the university community, to be there:

There is a wide diversity within [name of university] of students: this is most evident when one is in the student centre. When I am here I never feel like an outcast in that I know that I can find a group of students which I fit into. (BM)

In the library, I feel that the divisions along race, class, age and other diverse aspects become less important. This for me holds especially true in terms of feeling safe on a psychological level among people. (CF)

Second, participants described the commonality of purpose and sense of community and sharing that was evident in some eating and living spaces, which reportedly enhanced feelings of safety:

I experienced a feeling of community at the dining hall, perhaps due to the fact that fellow students and I was enjoying a meal together as if we were at home. (CF)

There is a great amount of diversity with varying races, genders and nationalities blending together and living in harmony [residence], which creates a welcoming, accepting, enjoyable and secure environment for me. (BF)

This sense of commonality of purpose and goal was further experienced through pedagogical practices that drew on group or team work, which reportedly diffused differences and facilitated a sense of group identity:

Another reason that makes a class a safe space is that there [is] group work ... that make students to become close to one another laughing and chatting while discussing within the group, and that brings about closeness. This space is safe for me because everyone treats one another with respect and we all become one. (BF)

It is known that students that are committed to their studies are often occupying the library. The library is occupied with students that share the common goal to do assignments, therefore this place is not occupied by careless and potentially threatening social identities. (CF) 
Third, and most significantly, participants also found that some lecturers and departments created spaces where diversity was encouraged, and where differences of opinions and perspective were invited. The methodologies used in the classroom that allowed for a more participatory and personalized approach seemed important in facilitating this sense of safety:

The lecturer creates a safe space for us as students ... Whilst sitting in the lecture, the case of inferiority, afraid of answering something or voicing my opinion doesn't occur. (CF)

I feel very safe during these tutorials. I believe that this is mainly due to the democratic and direct approach to learning that is taken there, and the genuine concern. (WF)

A significant component of this was an experience of being treated respectfully and recognized and valued for their diverse contributions:

As an African man I always feel treated with respect and the level of sensitivity when listening to each student's needs. The understanding that each student is different and they have different needs and should be treated differently has always been outstanding for me in [names department]. (BM)

Lecturers are very much in control and do their best to cultivate respect that will benefit everyone in the room ... The treatment is the same towards lecturers and among students themselves. The environment does not allow people to behave or see themselves as different from others, not even better than others or anyone to be bullied. (BF)

Moreover, some disciplines and units were regarded as specifically focused on issues of diversity and strove actively to deal with the challenges of marginalization and discrimination:

[Name of department] is about accepting human diversity and so lecturers always express the importance of practicing such behavior . . . this kind of mental capacity makes it comfortable for me to express who I really am as a person and not feel judged. (BF)

This [name of unit] is a space where students experiencing similar challenges on and off campus come together to learn from each other's experiences and shared stories. It has allowed me to feel comfortable about my sexuality. The relaxed and open environment made me feel welcome. (CF)

In sum, findings provide rich insight into current experiences of social identity and how they shape feeling safe and unsafe on campus. However, the study is limited in that it is a qualitative study at one university, with some of the issues particular to this campus. Furthermore, the student- researchers involved were located in a discipline particularly sensitive to issues of difference and social identity. 


\section{Conclusion}

Central to student experiences of campus life as emerges in this study is the recalcitrance of racialized, gendered, classed, sexualized, and other forms of assumed social identity, clearly in common and normative use by students (Seekings, 2008; Whitehead, 2012). Intersecting in complex ways, these are reportedly key in shaping feelings of being safe or unsafe. Both social-psychological discomfort in spaces where students feel 'othered' or marginal, and feelings of physical lack of safety, hinge around particular social identities and intersectional power inequalities, as shown in other local studies (e.g. Bradbury \& Kiguwa, 2012; Pattman, 2007). Of concern are not only the reported lived experience of continued othering practices on the basis of binaristic categories of identity but also the way in which essentialized notions of identity are assumed and reiterated in these narratives.

At the same time, the study also documents growing spaces for contestation of rigid categorization. Narratives on experiences of safeness foreground the way in which difference and diversity can be strategically mobilized to enhance positive experiences and a sense of belonging and safety for diverse students, as work by Whitehead (2012) suggests. At the most material level, the availability of common spaces, where diverse students gather to engage in common practices of living and learning, with a sense of identification of purpose and experience, are reported by students to facilitate a sense of belonging and safety. This may speak to the need to reflect more critically on the geographies of campus life and to assess the kinds of spatial resources available for such engagements.

Also, of particular value in thinking about social justice pedagogies in the larger project of developing critical citizenship, students report how working together with other students, across apparent group identity differences, also facilitates a sense of belonging and safety. Similarly, classrooms that draw on democratic teaching and learning values through active and participatory methodologies where student voices are encouraged and valued, facilitate an ethics of care (Tronto, 1993, 2013) in which students feel respected and therefore safe. Thus, the study highlights the importance of students feeling recognized in classrooms that appreciate them both as people from diverse backgrounds and experiences, as well as acknowledge their contributions to a democratized practice of knowledge production.

\section{Funding}

The authors declared receipt of the following financial support for the research, authorship, and/or publication of this article: This work is based on research supported in part by the National Research Foundation. Any opinion, findings and conclusions or recommendations expressed in this material are those of the authors and therefore the NRF does not accept any liability in regard thereto.

\section{Notes}

1. Current uses of apartheid terms are contested, and while politically Black has been used to refer to all those historically disenfranchised by apartheid, here we use Black to refer to those historically categorized as African or Black African, and Coloured to those historically

\section{http://repository.uwc.ac.za}


categorized in this way (mixed 'race'). While we reject such racialized categories, they continue to be used for the purpose of redress and continue to have salience (Zeleza, 2006), as this article shows, for shaping group identity.

2. We spell out the gender and raced identity in full in the first use and thereafter provide acronyms.

3. We are grateful to the anonymous reviewer who provided this insight. 


\section{References}

Badat, S. (2016). Deciphering the meanings, and explaining the South African Higher Education student protests of 2015-2016. Retrieved from https://mellon.org/resources/shared-experiences-blog/south-africaprotests/

Bennett, J. (Ed.). (2005). Killing a virus with stones? Research on the implementation of policies against sexual harassment in Southern African Higher Education. Cape Town, South Africa: African Gender Institute.

Bernardino-Costa, J. (2014). Intersectionality and female domestic workers' unions in Brazil. Women's Studies International Forum, 46, 72-80.

Bhana, D. (2014). Race matters and the emergence of class: Views from selected South African university students. South African Journal of Higher Education, 28, 355-367.

Bozalek, V., \& Boughey, C. (2012). Misframing higher education in South Africa. Social Policy and Administration, 46, 688-703.

Bozalek, V., \& Carolissen, R. (2012). The potential of critical feminist citizenship frameworks for citizenship and social justice in higher education. Perspectives in Education, 30, 9-18.

Bozalek, V., Carolissen, R., Nicolls, L., Leibowitz, B., Swartz, L., \& Rohleder, P. (2010). Engaging with difference in Higher Education through collaborative inter institutional pedagogical practices. South African Journal of Higher Education, 24, 1023-1037.

Bradbury, J., \& Kiguwa, P. (2012). Thinking women's worlds. Feminist Africa, 17, 28-47.

Clowes, L. (2013a). The limits of discourse: Masculinity as vulnerability. Agenda, 27, 12-19.

Clowes, L. (2013b). Teacher as learner: A personal reflection on a short course for South African university educators. Teaching in Higher Education, 18, 709-720.

Condy, J. (Ed.). (2015). Telling stories differently: Engaging 21st century students through digital storytelling. Cape Town, South Africa: SUN MeDIA.

Badat, S. (2016). Deciphering the meanings, and explaining the South African Higher Education student protests of 2015-2016. Retrieved from https://mellon.org/resources/shared-experiences-blog/south-africaprotests/

Bennett, J. (Ed.). (2005). Killing a virus with stones? Research on the implementation of policies against sexual harassment in Southern African Higher Education. Cape Town, South Africa: African Gender Institute.

Bernardino-Costa, J. (2014). Intersectionality and female domestic workers' unions in Brazil. Women's Studies International Forum, 46, 72-80.

Bhana, D. (2014). Race matters and the emergence of class: Views from selected South African university students. South African Journal of Higher Education, 28, 355-367.

Bozalek, V., \& Boughey, C. (2012). Misframing higher education in South Africa. Social Policy and Administration, 46, 688-703.

Bozalek, V., \& Carolissen, R. (2012). The potential of critical feminist citizenship frameworks for citizenship and social justice in higher education. Perspectives in Education, 30, 9-18.

Bozalek, V., Carolissen, R., Nicolls, L., Leibowitz, B., Swartz, L., \& Rohleder, P. (2010). Engaging with difference in Higher Education through collaborative inter institutional pedagogical practices. South African Journal of Higher Education, 24, 1023-1037.

Bradbury, J., \& Kiguwa, P. (2012). Thinking women's worlds. Feminist Africa, 17, 28-47.

\section{http://repository.uwc.ac.za}


Clowes, L. (2013a). The limits of discourse: Masculinity as vulnerability. Agenda, 27, 12-19.

Clowes, L. (2013b). Teacher as learner: A personal reflection on a short course for South African university educators. Teaching in Higher Education, 18, 709-720.

Condy, J. (Ed.). (2015). Telling stories differently: Engaging 21st century students through digital storytelling. Cape Town, South Africa: SUN MeDIA.

Robus, D., \& Macleod, C. (2006). White excellence and black failure: The reproduction of racialised higher education in everyday talk. South African Journal of Psychology, 36, 463-480.

Rohleder, P., Swartz, L., Bozalek, V., Carolissen, R., \& Leibowitz, B. (2008). Community, self and identity: Participatory action research and the creation of a virtual community across two South African universities. Teaching in Higher Education, 13, 131-143.

Seekings, J. (2008). The continuing salience of race: Discrimination and diversity in South Africa. Journal of Contemporary African Studies, 26, 1-25.

Shefer, T. (2016). Resisting the binarism of victim and agent: Critical reflections on 20 years of scholarship on young women and heterosexual practices in South African contexts. Global Public Health: An International Journal for Research, Policy and Practice, 11, 211-223.

Shefer, T., \& Clowes, L. (2015). Authentic learning in an undergraduate research methodologies course. In V. Bozalek, D. Ng'ambi, D. Wood, J. Herrington, J. Hardman \& A. Amory (Eds.), Activity theory, authentic learning and emerging technologies: Towards a transformative higher education pedagogy (pp. 80-91). London, England: Routledge.

Shefer, T., Clowes, L., \& Vergnani, T. (2012). Narratives of transactional sex on a university campus. Culture, Health \& Sexuality: An International Journal for Research, Intervention and Care, 14, 435-447.

Soudien, C. (2012). Realising the dream: Unlearning the logic of race in the South African school. Cape Town, South Africa: HSRC Press.

Suffla, S., Kaminer, D., \& Bawa, U. (2012). Photovoice as community engaged research: The interplay between knowledge creation and agency in a South African study on safety promotion. Journal of Psychology in Africa, 22, 517-526.

Tronto, J. (1993). Moral boundaries: A political argument for an ethic of care. New York: Routledge.

Tronto, J. (2013). Caring democracy: Markets, equality, and justice. New York: New York University Press.

Vincent, L. (2008). The limitations of interracial contact: Stories from young South Africans. Ethnic and Racial Studies, 31, 1426-1451.

Wang, C., \& Burris, M. A. (1997). Photovoice: Concept, methodology and use for participatory needs assessment. Health, Education \& Behaviour, 24, 369-387.

Whitehead, K. (2012). Racial categories as resources and constraints in everyday interactions: Implications for racialism and non-racialism in post-apartheid South Africa. Ethnic and Racial Studies, 35, 1248-1265.

Zeleza, P. (2006). The inventions of African identities and languages: The discursive and developmental implications. In O. Arasanyin \& M. Pemberton (Eds.), Selected Proceedings of the 36th annual conference on African linguistics (pp. 14-26).

\section{http://repository.uwc.ac.za}


Somerville, MA: Cascadilla Proceedings Project. Retrieved from http://www.lingref.com/cpp/acal/36/paper1402.pdf 